\title{
Partnership Management of Fishing Vessel of Nautica Study Program (Case Study at State Vocational High School 1 Pemangkat)
}

\author{
Tan Hero ${ }^{1)}$, Aswandi ${ }^{2)}$, M.Chiar ${ }^{3)}$ \\ ${ }^{1)}$ Universitas Tanjungpura, Pontianak, Indonesia \\ E-mail: hero_azza@yahoo.co.id \\ ${ }^{2)}$ Universitas Tanjungpura, Pontianak, Indonesia \\ E-mail: aswandiwk@yahoo.com \\ ${ }^{3)}$ Universitas Tanjungpura, Pontianak, Indonesia \\ E-mail: chiarfkip@gmail.com
}

\begin{abstract}
The Nautical fishing vessel study program is the most superior study program compared to the other four (4) Study Programs. The uniqueness of Nautical fishing vessel study program is a very prominent partnership with the business world that is able to establish cooperation with companies in Asia and Europe in the form of a dual system education and graduate distribution to the world work. This study aims to clearly describe the partnership management of the Nautical Fishing Vessel Study Program in SMKN 1 Mapping formulated in several research questions with the principles of planning and implementation of management. The approach used in this research is qualitative descriptive with case study research type namely 1) Data Reduction, done by reviewing all data obtained well through the interview; 2) Display Data, namely by systematize principal information with the theme and pattern that appears to be in accordance with the conclusions of data collected will be meaningful; 3) Taking conclusions and data on the summary of information data that appears in the Display data, simple data, meaning, solid conclusions are made. The data obtained in the study is processed qualitatively based on the answers obtained by way of describing the answer in the form of conclusion. Summaries conducted to conduct analysis of research findings among other: a) Understanding of the object between the first of the SMK and second party World business / industrial world; b) mutual agreement which is the initial stage of good cooperation between the parties concerned; c) joint actions to achieve the objectives of the partnership: mutual benefit between the two parties.
\end{abstract}

Keywords: Management; Partnership; Nautical of fishing vessel

\section{INTRODUCTION}

Management is the science, art, and process of planning, organizing, directing, and overseeing organizational resources, carried out with people to achieve established goals. While partnerships according to experts is a business strategy undertaken by two or more parties, on the principle of mutual need. From the above definition can be concluded that partnership management is a process in organizing and providing direction of work to the people in an organization to achieve the goals of both parties with the principle of mutual need and benefit.

Vocational School Vocational School Partnership Management (SMK) is an effort or act of planning, organizing, moving, and controlling study program in which there are people who direct activities with the world of education ie students, teachers, principals, vice principals, and Head of Vocational School Study Program (SMK). One of the vocational schools in Pemangkat is SMK Negeri 1 Pemangkat has several partnership network distribution/marketing graduates Nautica Fishing Vessel (NKPI) Program in Vocational High School (SMK) Negeri 1 Pemangkat include: 1. CV.PRILA MARITIM CENTER (BALI), 2. PT.SAFAR ABADI (JAKARTA), 3. PT, SEI (JAPAN), 4. PT. MITRA BAHARI (JAPAN), 5. CV.GILONTOS (PANAMA) (Document Source Study Program NKPI Sekolah Menengah Kejuruan Negeri 1 Pemangkat).

SMK Negeri 1 Pemangkat is a formal vocational education institution that focuses its activities on fisheries, agribusiness and information technology consisting of 5 (Five) study programs namely Nautical Fishing Vessel, 
Agribusiness of Aquatic Resources Production, Transmission Telecommunication Engineering, Fishing Vessel Engineering and Processing Technology of Fishery Products. The nautical fishing vessel study program is part of the Fishery vessel Study Program and the Study Program whose existence has received a positive response from the public in many of the four other study programs with evidence of the number of people who send their children to school, partnership management in work practice/education system double up to marketing graduates from within the country to foreign countries, and of course be a favourite in community and prospective students to proceed to SMK Negeri 1 Pemangkat, it certainly did not escape from the good managerial touch of the program chairman the study of Nautika Fishing vessel.

Based on the facts of data available at State Vocational High School 1 Pemangkat of the five existing Study Programs, Nautika Fish Catcher Study Program is the most superior study program compared to the other four courses. The uniqueness of Nautika ship program Fishing is a very prominent management of partnership with the World business / Industrial World is able to establish cooperation with companies in Asia and Europe in the form of double system education and distribution of graduates to the world of work so that there is a significant difference with the program other studies that exist in SMK Negeri 1 Pemangkat.

The reality is very different in the other four courses in SMK Negeri 1 Pemangkat relationship Partnership with the business world and the industry has not been able to meet the demands of the objectives of the study program. Future hope, of course, Nautika Fish Catcher Study Program can be role model for another study program at SMKN 1 Pemangkat especially and Vocational High School in Sambas Regency in general. Obviously the education process will run well if within the school there is a good management system, this is in accordance with the management function is the process of planning, organizing, implementation and supervision of the efforts of members of the organization and the use of other organizational resources in order to achieve organizational goals that have been set.

Encouraged by the desire to know the efforts undertaken in Management Studies Program at SMK Negeri 1 Pemangkat, the authors are keen to conduct research on "Management of partnership nautical fishing vessel study program at SMKN 1 Pemangkat".

\section{RESEARCH METHOD}

In this research used descriptive research method with qualitative approach. Descriptive research is a study that attempts to describe a phenomenon, events, events that occur today. Through descriptive research, researchers try to describe the events and events that became the center of attention without giving special treatment to the event. Data collection is done through observation, interview, and documentation.

\section{RESULT AND DISCUSSION}

A. Result

1. The principle of partnership

a. Transparency

In partnership management of nautical fishing vessel study program, one of the principal partnership items is transparency between the schools namely Nautika fishing vessel ship program and the business world/industry world that is transparency of information management and financial management transparency. From the interviews, it is known that the existence of the principle of partnership is transparency between the two parties who are partnering on the rights and obligations of both partners of implementing partnership SMKN 1 Pemangkat and the company and known cadets as the executor of the results of partnership. This can be reinforced from the documentation of the researcher in the form of documentation of contract agreement in the form of copy of MOU draft between SMKN 1 Pemangkat and partner company of business world/industry world.

b. Accountable

Based on the next observation related to the second principle of partnership that is accountable can be justified mutual agreement that is as early stages of a good cooperation between the parties concerned can be seen the draft MOU signed by both parties taped stamp Rp 6000 (six thousand rupiahs) as the legal basis that can be justified.

c. Partiality

In subsequent interviews relate to the third principle of partnership is the siding of the cadets as the perpetrator in the implementation of partnership in the form of salary in addition to having the opportunity to gain knowledge through industrial work practices and as a condition of class increase in addition to the cadets given the opportunity at accept work in the company in their place of industrial work practice as a form of distribution of graduates and of course there is a stage of further selection. Based on the results of interviews conducted can be concluded that there are alignments against cadets in addition to receiving knowledge and compensation in the form of salaries of alumni also got a chance to be recruited into a workforce in a company that became a partner of SMKN 1 Pemangkat.

d. Equality

On the principle of equality of Individuals, organizations or institutions that have been willing to forge partnerships should feel the same or parallel position with others in achieving the objectives agreed From the interview results can be concluded that the principle of partnership, in this case, equality is the existence of equal position between the two parties who partner on the basis of mutual need.

e. Mutualism

The principle of mutual partnership is mutual benefit is a strong foundation in building partnerships. If in partnership there is one party who feel harmed or feel no 
more benefits, it will disrupt the harmony in working together. Between the partners should contribute to each other according to their respective roles and should feel mutual benefit from the partnership. Based on the data obtained from the interviews can be concluded between parties who partnered each other to contribute according to their respective roles and must feel mutually benefited with the existence of partnership through the School provides labor-ready training and have the character and ability while the world of work to get the workforce who are physically ready to work.

2. Management Principles.

a. Planning

Planning is identifying goals for future organizational performance as well as deciding on the task and use of the resources needed to achieve it. In other words, managerial planning determines the position of the organization in the future and how to achieve it. Partnership planning among others is the assessment, equalization perception, role setting, intensive communication, conducting activities, and the last monitoring and assessment. Partnership planning process in SMK N 1 Pemangkat especially on Nautika study program of fishing vessel there is a process or stages through; 1) the assessment process conducted by the study program team; 2) the existence of role arrangements that are in form of meeting results in the study program; 3) communication between schools and potential partners; 4) engaging in an agreement, and 5) the monitoring and assessment of potential partners is feasible or not as a place of industrial work practices.

b. Organizing

Organizing is usually done after planning and reflects how the organization tries to realize the planning. The existence of a structured implementation of the work in the form of implementing teams in the smallest organization. The principal is the ultimate responsibility in the management of the partnership to give full authority to the head of the study program as manager of partnership to partner with the Business World/ Industrial world and then the Head of the study program to make the organizational structure according to the main task and function and form the organizing committee for partners and institutions pairs relevant to the course of study. From the interview result, the researcher concludes that the management in SMKN 1 Pemangkat is the existence of a system of organizational activities in a structured and coordinated starting from the principal as the responsible person and the study program as the executor wherein the study program there is a structured division of tasks to carry out their main tasks and functions according to organizational goals.

c. Leadership

A leader uses influence to motivate subordinates to achieve organizational goals. Achieving or not the goal depends on whether or not the entire group of management members, from the top, middle to the bottom level. The results of interviews conducted at the
SMKN 1 Pemangkat obtained the results of whether or not the goal is achieved depends on whether or not moving the entire membership of the management group, ranging from upper, middle to bottom level is the support of leaders to motivate subordinates by preparing funds to facilitate the work given to subordinates so that the subordinate without weight to perform the task assigned.

d. Controlling

Controlling means monitoring the employee's activity, determining whether the organization is aligned with its objectives, and making corrections where appropriate. The controls in the partnership are the first step in making the partner feel comfortable in partnering and sustaining. Based on the interviews, the conclusion is that control or supervision in SMKN 1 Pemangkat is done by maintaining the good reputation of the school by equipping the cadets with skill, attitude, discipline and mental to maintain the integrity of partnership with the company and supervise the activities if there is any agreement MOU or problem as soon as conveyed and resolved with partner institutions.

\section{B. Discussion}

1. The principle of partnership

a. Transparency

The findings of researchers through interviews related to the principle of transparency is known that the principle of partnership is the transparency between the two parties who are partnering on the rights and obligations of both partners implementing partnership SMKN 1 Pemangkat and the company and known cadets as executor of the results partnership. This can be reinforced from the documentation of the researcher in the form of documentation of contract agreement in the form of copy of the MOU draft between SMKN 1 Pemangkat and the partner company of the business world/industry. The findings are supported by Guratno Hartono (2012: 2) in the technical manual of partnership that the implementation of bias activities is known by all actors and communities and partnerships are based on a spirit of openness for partners.

b. Accountable

The findings of researchers through observation related to the second principle of partnership that is accountable to be accountable mutual agreement that is as early stages of a good cooperation between parties concerned can be seen the draft MOU signed by both parties taped stamp Rp 6000 (six thousand rupiahs) as the legal basis that can be justified. The findings are supported by Guratno Hartono (2012: 2) in the technical manual of partnership that the implementation of activities and partnerships that occur can be legally and socially responsible.

c. Partiality

The findings of the researcher through interview results related to the principle of alignment of the alignment against cadets in addition to receiving knowledge and rewards in the form of salaries of alumni also got a 
chance to be recruited into a workforce in the company that became a partner of SMKN 1 Pemangkat.

d. Equality

The findings of the researcher through interviews related to the principle of equality of partnership principle in this case equality is the existence of equal position between the two parties who partner on the basis of mutual need. The findings are supported by Guratno Hartono (2012: 2) in the technical manual of partnership that the parties who will conduct the partnership have equal position.

e. Mutualism

The findings of the researcher through the interviews related to the principle of mutualism that is between parties who partnered each other to contribute according to their respective roles and must feel mutual benefit from the partnership through the School provides the workforce ready to train and, have the character and ability while the world of work get physically ready labor ready. The findings are supported by Guratno Hartono (2012: 2) in the technical manual of partnership that partnerships generate benefits for the parties.

2. Management Principles

a. Planning

The findings of researchers through the results of interviews on the principles of planning management (planning) in partnership planning there is a process or stages which has been passed that is 1) the process of assessment conducted by the study program team; 2) the existence of role arrangements that are in the form of the outcome of the meeting in the study program; 3) communication between schools and potential partners; 4) activities agreement; and 5) monitoring and assessment of potential partners worthy or not as a place of industrial work practices. The findings are supported by Richard L.daft (2010: 6) Planning means identifying goals for future organizational performance as well as deciding on the tasks and use of the resources needed to achieve them. In other words, management planning determines the position of the organization in the future and how to achieve it. This finding is also supported (Robbins, Stephen P, 2013: 7) namely as a process to make the activity resolved efficiently and effectively through other people. It is also strengthened in the PP. 19 of 2005 on National Education Standards.

b. Organizing

The findings of researchers through the results of interviews on the principles of organizing management (management) in SMKN 1 Pemangkat is the existence of a system of organizational activities in a structured and coordinated start the responsible principals and study programs as implementers wherein the study program there is a structured division of tasks to carry out the main task and functions in accordance with organizational goals. The findings are supported by Richard L.daft (2010: 7) Management is usually done after the planning and reflects how the organization tries to realize the planning. Organizing includes assigning tasks, grouping tasks, delegating authority and allocating resources across the organization. This finding is also supported by Terry (Sukarna, 2011: 46) also argued about the principles of organizing, as follows, namely:

- The objective or purpose.

- Departmentation or division of labor.

- Assign the personnel or placement of labor.

- Authority and Responsibility or authority and responsibility.

- Delegation of authority or delegation of authority.

The above statement in accordance with the organization's definition according to Hasibuan (2013: 24) is "a formal, structured and coordinated union system of groups of people who work together in achieving certain goals".

c. Leadership

The findings of the researcher through interviews about the principle of leading management (leadership) that the achievement or absence of goals depends on whether or not the entire group of management members, from the top, middle to bottom level is the support of leaders to motivate subordinates by preparing funds to expedite the work given to subordinates so that subordinates without weight to perform the task assigned. The findings are supported by Richard L.daft (2010: 8). Leadership means using influence to motivate employees to achieve organizational goals. Leadership means creating shared values and culture, communicating objectives to employees throughout the organization, and injecting spirit to show the highest performance to employees. The statement is also supported by Sukarna (2011: 8283). Factors that are required for the mobilization are:

- Leadership

- Attitude and morale

- Communication

- Incentive

- Supervision

- Discipline

d. Controlling

The findings of the researcher through interviews on the principle of management control. Control or supervision is done by maintaining the good reputation of the school by providing cadets with skill, attitude, discipline and mental in order to maintain the integrity of partnership with the company and supervise the activities if there is any agreement MOU or the problem is promptly conveyed and resolved with partner institutions. The findings are supported by Richard L. (2010: 7). Controlling means monitoring employee activity, determining whether the organization is aligned with its objectives, and making corrections where necessary. Managers must ensure that their organization moves towards its goals. The statement was also supported by Sukarna (2011: 116), proposed the following oversight process:

1. Determining the standard or basis for control (determining the standard or basis for supervision).

2. Measuring the performance. 
3. Comparing performance with the standard and finding the difference, it any (compare the implementation with the standard and find if there is a difference)

4. Correcting the deviation by means of remedial action (correct the deviation by appropriate means of action).

\section{CONCLUSIONS AND SUGGESTIONS}

\section{A. Conclusions}

Based on the results of qualitative research with observation techniques, interviews and documentation conducted at SMK Negeri 1 Pemangkat about partnership management program Nautical fishing vessel ship can be taken some conclusions in accordance with the data obtained by researchers. The conclusion can be described as follows:

1. The existence of the principle of partnership is the transparency between the two parties who are partnering on the rights and obligations of both parties implementing partnership SMKN 1 Pemangkat and the company and known cadets as the executor of the results of partnership.

2. The principle of partnership that is accountable to be accountable mutual agreement that is as early stages of a good cooperation between parties concerned.

3. The existence of alignments against cadets in addition to receiving knowledge and rewards in the form of salary of alumni also got a chance to be recruited into a workforce in a company that became a partner of SMKN 1 Pemangkat.

4. The principle of equality in partnership is the existence of an equal position between the two parties who partner on the basis of mutual need.

5. The principle of mutualism is between parties who partner mutually contribute according to their respective roles and must feel mutual benefit from the partnership.

6. Partnership planning there are some process or stages that are passed namely 1) the process of assessment conducted by the study program team;2) the existence of role arrangements that are in form of meeting results in the study program; 3) communication between schools and potential partners; 4) engaging in an agreement; 5) the monitoring and assessment of potential partners is feasible or not as a place of industrial work practices.

7. Management management principles in SMKN 1 Pemangkat.

8. Principles of leadership management that the achievement of goals is not dependent on whether or not all members of the management group move.

9. The principle of control management is control or supervision is done by maintaining the good name of the school by equipping cadets with skill, attitude, discipline and mental.

B. Suggestions

Based on the results of this study can be given suggestions as follows:

1. Further research should be done by adding respondents from outside the element of the school such as from the business world/industrial world.

2. Further research can be developed again at the focus of research at the world level of business / industrial world.

3. The results of this study may be a reference for the development of other expertise study programs in order to support government programs that reduce the unemployment rate to prepare a vocational graduate ready for work.

\section{REFERENCES}

Daft, Richard L. 2010. Era Baru Manajemen Edisi 9 Buku 2. Jakarta: Salemba Empat.

Hasibuan, Malayu. 2013. Manajemen Sumber Daya Manusia. Edisi Revisi.Jakarta: PT Bumi Aksara.

PP No. 19 tahun 2005 tentang Standar Nasional Pendidikan (SNP)

Robin, Stephen, P., Mary, C. 2013. Manajemen. Jakarta: Erlangga.

Sukarna. 2011. Dasar-Dasar Manajemen. Bandung: CV. Mandar Maju. 